\title{
Effect of snow depth on under-ice irradiance and growth of Aulacoseira baicalensis in Lake Baikal
}

\author{
David H. Jewson • Nick G. Granin • \\ Andre A. Zhdanov $\cdot$ Ruslan Yu Gnatovsky
}

Received: 21 May 2009/Accepted: 1 July 2009/Published online: 15 July 2009

(C) Springer Science+Business Media B.V. 2009

\begin{abstract}
Lake Baikal freezes for 4-5 months each year; yet the planktonic diatoms that grow under the ice include some of the largest species found in freshwater. An important factor influencing their growth is the depth of snow. In this study, a population of Aulacoseira baicalensis developed where there was little or no snow on the ice but declined where there was $10 \mathrm{~cm}$ of snow, because $99 \%$ of the available light was attenuated. Culture studies of light response showed that $A$. baicalensis was adapted to relatively low light intensities $\left(<40 \mu \mathrm{mol} \mathrm{m} \mathrm{m}^{-2} \mathrm{~s}^{-1}\right)$ that were close to the average that a cell experiences in $\mathrm{L}$. Baikal when mixed vertically by convection to depths that can exceed $100 \mathrm{~m}$. On sunny days, cell division could be inhibited down to $>10 \mathrm{~m}$ depth but narrow $(<15 \mu \mathrm{m})$ diameter cells trapped in high light intensities in sub-ice layers switched to auxosporulation and size regeneration.
\end{abstract}

Keywords Diatom growth · Ice - Lake Baikal · Mixing $\cdot$ Phytoplankton $\cdot$ Snow

D. H. Jewson $(\square)$

Freshwater Laboratory, University of Ulster,

96 Desertmartin Road, Magherafelt,

County Londonderry BT45 5HE, UK

e-mail: d.jewson@btinternet.com

N. G. Granin · A. A. Zhdanov · R. Y. Gnatovsky Limnological Institute, Russian Academy of Sciences Siberian Division, P.O. Box 4199, 6644033 Irkutsk, Russia

\section{Introduction}

Lake Baikal freezes for 4-5 months each year (Shimaraev et al. 1994), and during this time, a distinct and abundant phytoplankton community develops (Kozhov 1963; Kozhova 1987; Kozhova and Izmest'eva 1998; Popovskaya 2000; Fietz et al. 2005; Jewson et al. 2008) that includes some of the largest diatoms found in freshwaters. The dominant species is Aulacoseira baicalensis (Meyer) Simonsen. It forms filaments over $1 \mathrm{~mm}$ long, with a diameter from 10 to $35 \mu \mathrm{m}$ (Skabichevsky 1929; Bidoshvili et al. 2007), and has been present in L. Baikal for hundreds of thousands of years (Grachev et al. 1998; Likoshway 1999). The presence of such large cells under ice is unusual for lakes, where small-celled or motile species often predominate (Rodhe 1955; Nauwerck 1963; Cronberg et al. 1975; Jónasson and Adalsteinsson 1979). So, physical processes must be sufficient to keep cells in suspension, and this has been considered in a theoretical analysis of the mixing conditions resulting from thermal convection in L. Baikal by Kelley (1997). In addition, the importance of salinity differences at the interface layer that develops between ice and water has been described by Granin et al. (1999, 2000).

From the early investigations of Skabichevsky (1929) in the 1920s, we know that A. baicalensis both grows and changes morphology under the ice. More recent work has shown that $A$. baicalensis can form dense mats under ice in calm conditions inshore, once 
ice stops increasing in thickness (Bondarenko et al. 2006), but we know little about the environmental factors controlling growth, especially the effects of snow depth. Mackay et al. (2005) speculated that the low numbers of fossilised A. baicalensis remains found in the middle basin, compared with the north and south basins, might be due to a greater frequency of clear ice resulting in photoinhibition. The aim of this work was to assess whether differences in the availability of light, caused by spatial variation in snow depth, affect the growth of A. baicalensis. The underwater light field in L. Baikal has been extensively described (Sherstyankin 1975) and productivity under the ice (Straškrabová et al. 2005) as well as growth in culture using changes in chlorophyll (Richardson et al. 2000) has been measured, but we do not know how the available light relates to changes in cell concentration. Therefore, in this study we combined culture studies measuring rates of cell increase under different light intensities with field studies in two areas of the lake with ice cover, one with deep snow and one with no snow. The work was carried out at a time when the ice had stopped increasing in depth but before it began to melt. Details of this and the thermal structure of the sub-ice layers in the period before and during the study are given in Granin et al. (1999).

\section{Methods}

Vertical phytoplankton samples were collected during March 1994 using 31 closing bottles at 0, 5, 10, $15,25,50,100$ and $150 \mathrm{~m}$ in the south basin of $\mathrm{L}$. Baikal at the largely snow-free site, which was $7 \mathrm{~km}$ from Lystvyanka (51 ${ }^{\circ} 46^{\prime} 94 \mathrm{~N}$ : $\left.104^{\circ} 56^{\prime} 92 \mathrm{E}\right)$, and the snow-covered site, which was $8 \mathrm{~km}$ from Tankhoi $\left(51^{\circ} 38^{\prime} 19 \mathrm{~N}\right.$ : $105^{\circ} 03^{\prime} 98 \mathrm{E}$; Fig. 1). Methodology in this study was the same as that used in a longer-term investigation (Jewson et al. 2008) where phytoplankton cells were preserved by adding Lugol's iodine to 1.5 or 31 of lake water immediately on collection. Samples were later concentrated by allowing cells to settle for 10 days then reducing the volume to $30 \mathrm{ml}$ by gentle siphoning. Cells were counted in settlement chambers using an inverted Olympus IM microscope.

For cultures, live cells were collected under the ice by vertical net hauls, and individual filaments selected and then grown in separate chambers of 24-well flatbottom microtitre tissue plates (Jewson et al. 2008).

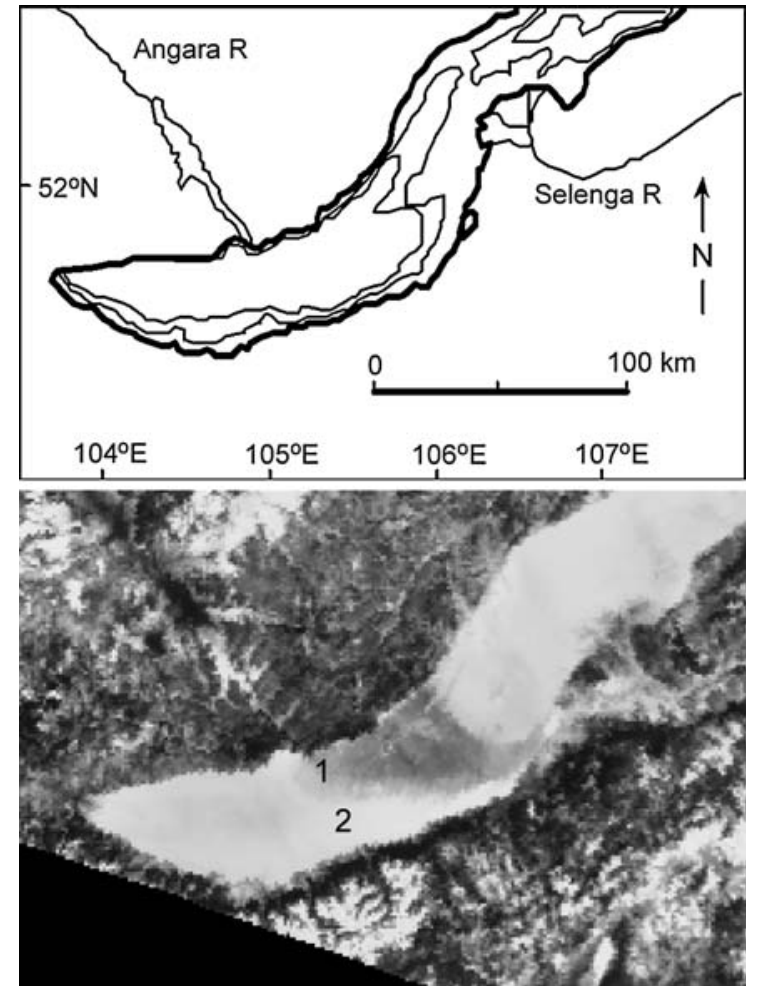

Fig. 1 Map of south basin of L. Baikal showing the 400 and 1,000 $\mathrm{m}$ isobaths and satellite (AVHRR) picture on 24 March 1994 showing the distribution of snow cover (white) and clear ice (dark). The numbers mark the approximate positions of the snow-free site (1) and snow-covered site (with up to $10 \mathrm{~cm}$ snow depth) (2)

For the experiments, five individual filaments were placed in separate chambers in each of five different microtitre plates, which were then placed in a light gradient in a Phytotron kept in a constant-temperature room at $4^{\circ} \mathrm{C}$ and illuminated $\left(25 \mu \mathrm{mol} \mathrm{m} \mathrm{m}^{-2} \mathrm{~s}^{-1}\right)$ by fluorescent tubes (cool white Osram $30 \mathrm{~W}$ ) on an 8:16 light-dark cycle. Cell numbers along each filament in the separate chambers of the microtitre plate were counted once or twice daily on an inverted microscope (Olympus Ltd, model IM). The experiments lasted for two doublings at optimal irradiances (about 1 week) but up to 16 days in the irradiances where there was low or no growth.

Irradiances were measured with Li-Cor LI-185B and LI-190SB quantum sensors (Li-Cor, Inc., Nebraska, USA). Temperature profiles were made with CTD (conductivity-temperature-depth) models, AML-12 (Applied Microsystems, Canada) and SBE25 (Sea-Bird Electronics, USA). 


\section{Results}

There was extensive coverage of snow across the southeastern part of the basin on 24 March 1994 (Fig. 1), with snow depths over $10 \mathrm{~cm}$, but to the northwest, the prevailing winds had blown most of the snow away and left large areas of clear ice. This is typical of the distribution found in most years. Site 1 was in the area of clear ice, and Site 2 was in the area of snow cover up to $10 \mathrm{~cm}$ deep (Fig. 1). Both sites were sampled just before the satellite picture in Fig. 1 was taken and also 2 weeks earlier, at the beginning of March. The depth distributions of temperature at the two sites (Fig. 2) provide an indication of the
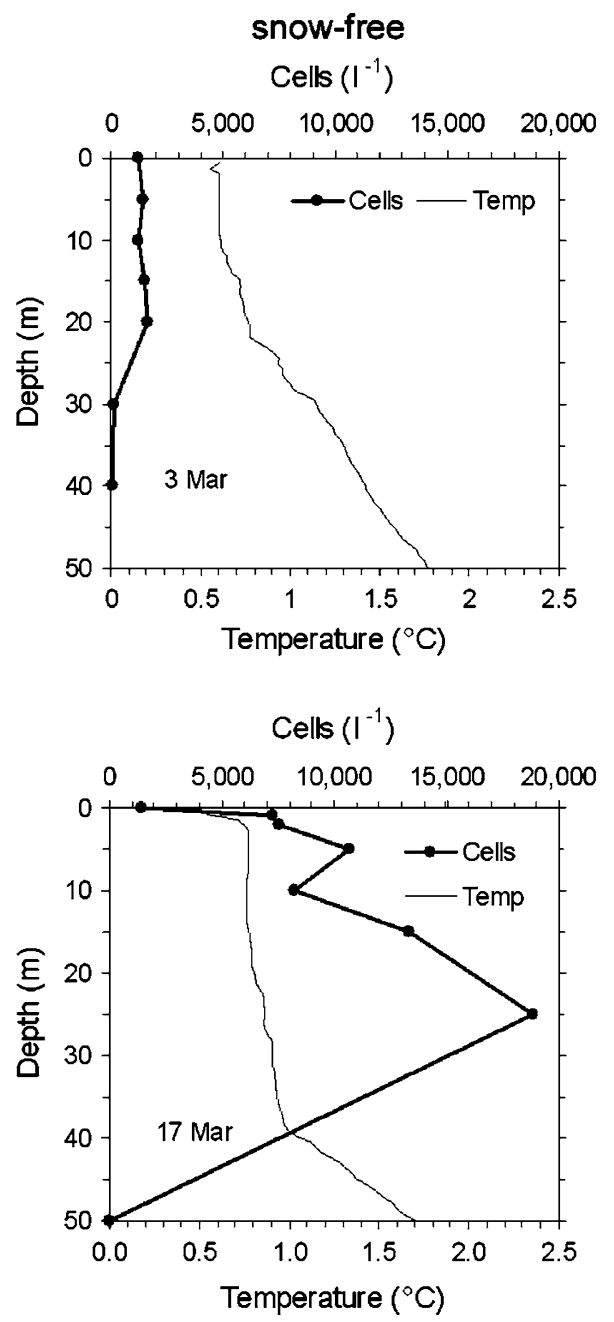

different vertical mixing conditions experienced by phytoplankton. At the beginning of March at the snow-free site, the isothermal depth distribution of temperature down to $10 \mathrm{~m}$ showed that convection was strengthening, as the seasonal increase in solar radiation began to take effect. Cells were mixed throughout this layer, but concentrations were still relatively low, varying from 1,200 to 1,600 cells $1^{-1}$ (Fig. 2). Between 10 and $20 \mathrm{~m}$, the depth distribution of temperature indicates that vertical mixing was reduced but it was not possible to determine whether the presence of cells was due to mixing, settling or advection. At the snow-covered site, snow depths were initially under $5 \mathrm{~cm}$, so there was less energy
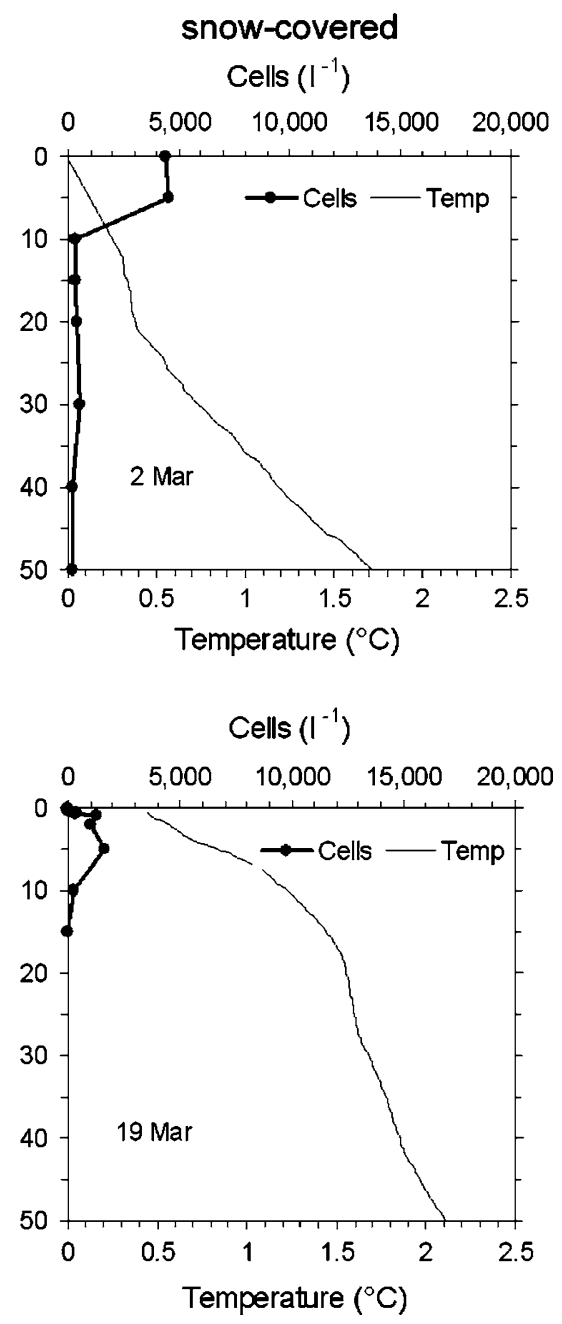

Fig. 2 Depth distributions of Aulacoseira baicalensis and temperature at snow-free and snow-covered sites in the south basin of Lake Baikal in March 1994 
from solar radiation penetrating through the ice and vertical mixing was less but cells $\left(4,500\right.$ cells $\left.1^{-1}\right)$ were present down to $5 \mathrm{~m}$ (Fig. 2). At this stage, in early March, the light history had been relatively similar at both sites and the number of cells of A. baicalensis integrated per unit area (down to $50 \mathrm{~m}$ ) was also similar (38 and 49 million cells $\mathrm{m}^{-2}$ ). However, over the next 2 weeks, light and mixing conditions at the two sites developed very differently. At the snow-free site, solar heating increased and convective mixing extended down to $40 \mathrm{~m}$. Concentrations of A. baicalensis cells increased (Fig. 2) and reached up to $20,000 \mathrm{I}^{-1}$ at individual depths and up to 300 million $\mathrm{m}^{-2}$. This represents a net increase in cell numbers equivalent to about three divisions or one division every 5 days over 2 weeks. This is an underestimate because it does not account for losses through grazing, auxosporulation or sedimentation. There was also the possibility that the same populations were not sampled due to horizontal water movements, but the temperature profiles at the snowfree site indicated a similar light history for the water masses (Granin, unpublished data). However, at the snow-covered site, there was an increase in temperature, suggesting advection. Moreover, differences developed between the sites in the layers immediately under the ice. In the snow-free site, a distinct layer formed due to decreasing density from melt water (see Granin et al. 1999) with fewer cells. Cells entrained in this layer that had diameters less than $50 \%$ of the maximum diameter switched from vegetative division to size regeneration, which is associated with the timing mechanism for sexual reproduction in many diatom species, with up to $30 \%$ of the cells forming auxospores that had an organic cell wall to allow cell expansion before a new silica cell wall was laid down in an enlarged cell. In contrast, at the snow-covered site on 19 March, the snow depth had increased to around $10 \mathrm{~cm}$ and the temperature profile showed that this under-ice layer did not develop in the same way and that convective mixing was negligible (Fig. 2). Cells were only found in the top $10 \mathrm{~m}$ and the concentration had fallen to around 1,000 $\mathrm{l}^{-1}$ (11 million $\mathrm{m}^{-2}$ ), with considerable numbers of cells in either poor condition (with fewer, pale chloroplasts) or empty. There was no auxosporulation found.

An important difference between the snow-free and snow-covered sites was in the amount of available light. To establish how the amount of available light affected A. baicalensis, growth rates were measured in cultures at different light intensities. The response was based on sustained cell doubling over several generations rather than instantaneous photosynthetic response, which can be misleading for understanding long-term population changes. The onset of light saturation of growth began at a relatively low intensity of $17 \mu \mathrm{mol} \mathrm{m} \mathrm{m}^{-2} \mathrm{~s}^{-1}$ and inhibition began above $40 \mu \mathrm{mol} \mathrm{m} \mathrm{m}^{-2} \mathrm{~s}^{-1}$, with complete inhibition at $65 \mu \mathrm{mol} \mathrm{m}{ }^{-2} \mathrm{~s}^{-1}$ (Fig. 3). The average doubling rate at optimal light intensities (at $3^{\circ} \mathrm{C}$ ) was 4.2 days but only 3 days in some cell strains. At the snow-free site, light attenuation by the ice accounted for about $65 \%$, so there was $460 \mu \mathrm{mol} \mathrm{m} \mathrm{m}^{-2} \mathrm{~s}^{-1}$ in the water layer immediately underneath it. This would have inhibited growth down to $14 \mathrm{~m}$, where the light intensity had decreased to $43 \mu \mathrm{mol} \mathrm{m}{ }^{-2} \mathrm{~s}^{-1}$ (Fig. 4). Below this depth, there would have been sufficient light for net growth, down to over $25 \mathrm{~m}$ (Fig. 4). In a separate experiment, testing the division of cells in situ in containers suspended for 3 days, from 22 to $25 \mathrm{March}$, at the snow-free site, no division or lengthening of cells before division was found in the upper $10 \mathrm{~m}$ where irradiances reached (at $10 \mathrm{~m}$ depth) up to $99 \mu \mathrm{mol} \mathrm{m} \mathrm{m}^{-2} \mathrm{~s}^{-1}$ (Jewson, unpublished data). So, conditions that had been favourable for growth in most depths during the first part of March then changed, with the increase in solar radiation sufficient on bright sunny days to check the growth of cells in the upper layers. On dull days, the incoming solar radiation below the ice dropped to $185 \mu \mathrm{mol} \mathrm{m} \mathrm{m}^{-2} \mathrm{~s}^{-1}$ but was still sufficient to inhibit cell growth. In the following year, $3 \mathrm{~cm}$ of snow at this site on 14 March 1995 was sufficient to

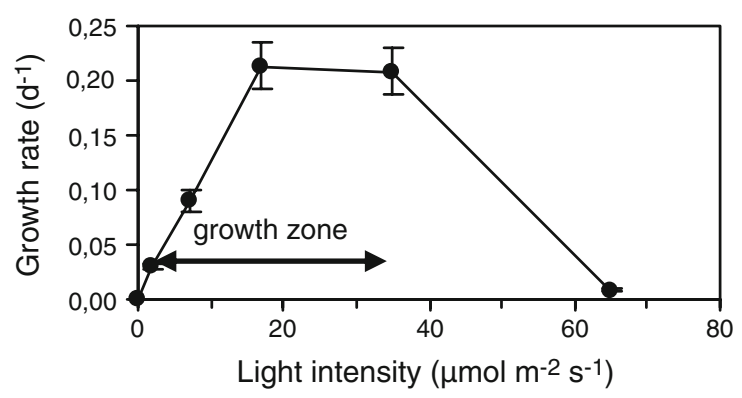

Fig. 3 The relationship between growth rate of Aulacoseira baicalensis and light intensity in cultured cells isolated from Lake Baikal in March 1997. Error bars, standard deviation 


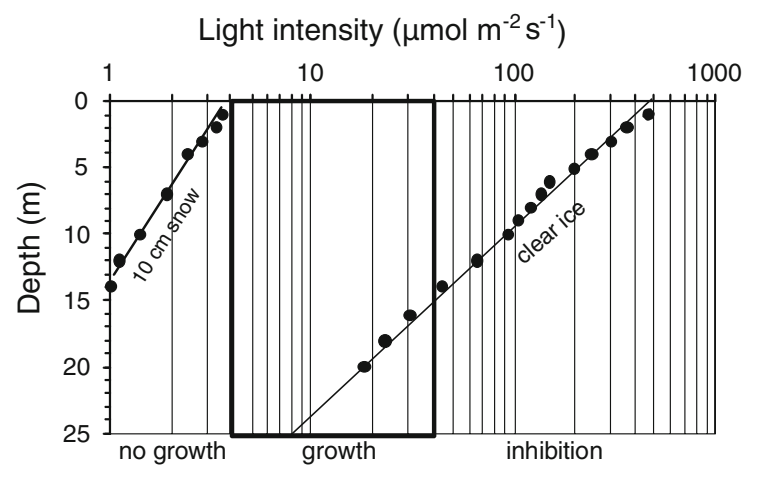

Fig. 4 The depth distribution of photosynthetically available radiation (400-700 $\mathrm{nm}$ ) in Lake Baikal under clear ice at the largely snow-free site on 17 March 1994 and at the site with $10 \mathrm{~cm}$ of snow on 19 March 1994. The potential zone for net growth of A. baicalensis (Fig. 3) is also shown

reduce the incoming solar radiation on a sunny day to $53 \mu \mathrm{mol} \mathrm{m} \mathrm{m}^{-2} \mathrm{~s}^{-1}$, so most of the light zone down to $15 \mathrm{~m}$ was in a range suitable for net increase of cells.

At the snow-covered site, with $10 \mathrm{~cm}$ depth of snow, $99 \%$ of the incoming solar radiation was scattered and absorbed by the snow, so that at the base of the ice, the light intensity on 19 March was $<5 \mu \mathrm{mol} \mathrm{m} \mathrm{m}^{-2} \mathrm{~s}^{-1}$. In the water, the vertical attenuation coefficient was lower $(0.09)$ at this site than at the snow-free site $\left(0.15 \mathrm{~m}^{-1}\right)$, but even so, by $10 \mathrm{~m}$ only $1 \mu \mathrm{mol} \mathrm{m} \mathrm{m}^{-2} \mathrm{~s}^{-1}$ was available (Fig. 3). This meant that even on the brightest days, net growth was only possible in the layer immediately under the ice. However, ice cores at this site found no cells growing on the base of the ice.

\section{Discussion}

Lund (1966) made the important point that under ice, the place where phytoplankton are sampled is not necessarily where they have grown, so they may have had a quite different light history. This is particularly true of L. Baikal, where Zhdanov et al. (2001) found strong horizontal currents generated under the ice, especially in boundary areas between clear and snowcovered ice. Average current speeds were $2 \mathrm{~cm} \mathrm{~s}^{-1}$, but maximum rates were up to $11 \mathrm{~cm} \mathrm{~s}^{-1}$, which means that, on average, cells could move by up to $1.7 \mathrm{~km}$ in a day and up to $9.5 \mathrm{~km}$ in certain circumstances. In contrast, under deep snow, they found that speeds were low, decreasing by an order of magnitude. These conditions of $10 \mathrm{~cm}$ snow and no snow were the two extremes chosen for the sites in this study (Fig. 1) because they illustrate the likely range of conditions that phytoplankton cells can encounter in L. Baikal.

As well as the changes experienced by cells moving horizontally under the ice, non-motile phytoplanktonic cells, such as diatoms, are subject to vertical convective mixing processes due to temperature (e.g. Kelley 1997) and salinity (Granin et al. 1999) that can take them through a range of light intensities from dark to bright light. Immediately under the ice, at the interface with the water, there is a layer where circulation is affected by density changes during ice formation caused by salting-out and during melting by dilution (Fig. 2). This layer can reach up to several metres (Granin et al. 1999). In spring, below this there is the main convective layer that may be absent under deep snow (Fig. 2) but can be more than $50 \mathrm{~m}$ under clear ice, eventually reaching over $100 \mathrm{~m}$ by ice break-up in late May or early June (Jewson et al. 2008). However, mixing in the convective layer is not consistent over $24 \mathrm{~h}$ because it declines at night when there is no solar energy to drive it or if there is cloud cover during the day. The observed gradient in the temperature curve of the ice-free site of L. Baikal in late March (Fig. 2) suggests that convection was weakening between 10 and $20 \mathrm{~m}$ (on sunny days, it would likely be isothermal) resulting in the increase in cell numbers with depth, i.e. a net sinking of cells. In fact, on this date, longer and broader diameter cells made up a higher proportion of the deeper population at $25 \mathrm{~m}$ (Jewson, unpublished data), showing how close the balance may be between sinking and staying in suspension. Once cells fall out of the mixing zone, they sink rapidly and are lost to deep water, e.g. virtually no cells were found by $50 \mathrm{~m}$ (Fig. 2).

Nutrients do play a role in limiting crops under the ice of L. Baikal in high biomass years (Jewson et al. 2008), but it is relatively minor compared with the main limiting factor of light. However, it is not just lower limits of light that are important. On sunny days in late March, the light intensity in the upper layers was high enough to inhibit the growth of A. baicalensis down to more than $10 \mathrm{~m}$ (Fig. 2), but below this there was still a layer of over $10 \mathrm{~m}$ that supported growth. The estimates of the inhibitory layer are 
based on midday values, but 24-h photosynthetic studies in Lough Neagh have shown that inhibitory conditions can persist for at least two-thirds of the day (Jewson 1975). The real problem for a population of algae comes if the depth of the mixing zone and the depth of inhibitory light levels are similar for extended periods of time. Such a likelihood increases during March, as solar elevation increases. In brighter conditions, acclimation to light is always a possibility and Richardson et al. (2000) have reported low growth rates at high light intensities. However, they used increases in filament length and chlorophyll $a$ as proxies for growth rather than the increase in cell numbers that were more appropriate for this study, but similar low light optima around $40 \mu \mathrm{mol} \mathrm{m} \mathrm{m}^{-2} \mathrm{~s}^{-1}$ for growth rates were found in both studies. It is possible that cells growing on the underside of the ice adapt but for freely circulating cells, it seems less likely. In 10 years of isolating and growing A. baicalensis in culture, it was never possible to get sustained cell division at high intensities (Jewson, unpublished data). What does happen in these layers with high light intensities is that narrow cells switch to auxosporulation and size regeneration, so exposure to high light intensities may be an essential part of their life cycle. At the other extreme of low irradiances, snow depths of $>10 \mathrm{~cm}$ cut out virtually all the light for growth and also increase the loss rate of cells, because the solar energy is less intensive to drive convection. In most years during the last decade in the south basin, the snow depth has been in a range somewhere between the two extremes measured in this study, so the adaptation of A. baicalensis to low light intensities is then understandable. However, in relating field and culture conditions, it is important to remember that cells in the lake are circulating vertically through a light gradient and not remaining stationary at one depth. Experiments by Jewson and Wood (1975) in a turbid lake showed that the main effect of circulation on photosynthesis in the euphotic zone was to reduce the impact of inhibition, so cells may still utilise higher light, if they do not remain in it too long.

Mackay et al. (2005) reported a correlation between low snow cover and low numbers of fossilised A. baicalensis remains in the sediments of the middle basin compared with the south and north basins. A possible cause for this would be whether the depth of the inhibitory zone made up a significant part of the mixing zone. At the moment, we do not have enough information about under-ice conditions in the middle basin in winter to prove or disprove this, but it is possible that the greater percentage of clear ice could reduce the rates of population increase sufficiently that they become vulnerable to other loss factors, such as grazing and sedimentation.

Large planktonic diatoms are not usually found under the ice in lakes, so the presence of two largecelled species such as A. baicalensis and Cyclotella baicalensis in L. Baikal immediately suggests an energetic mixing sufficient to support a net increase in cells. However, as seen in the difference between the snow-free and snow-covered sites, mixing due to convection can be highly variable, depending on time of day, cloudiness and snow depth. Therefore, it is not surprising that A. baicalensis has developed a number of adaptations to cope. For example, A. baicalensis cells freely circulating in the water under the ice are likely to sink more slowly because they produce shorter cells, which was first observed by Skabichevsky (1929) in a seasonal study in the 1920s and more recently by Bidoshvili et al. (2007). Culture experiments have shown that this change to shorter cells is related to the longer light period experienced by cells (Aslamov and Jewson, in press) when the mixing depth is reduced. Further, narrower cells trapped in the sub-ice layers with high irradiance at the snow-free site switched to size regeneration as part of their life cycle. In shallow, inshore areas, A. baicalensis has another strategy. When there are little or no currents, dense mats of cells may build up on the underside of the ice, once it stops increasing in thickness (Bondarenko et al. 2006). Long mucilage threads with filaments imbedded in them can then stretch several metres to the bottom near the shore. Having the ability to stay attached to the underside of the ice may be how A. baicalensis has survived in surrounding high alpine lakes (Bondarenko et al. 2006), where there is less convection than in $\mathrm{L}$. Baikal. It is a similar habitat to that of the marine diatom Melosira arctica (Ehr.) Dickie, which also forms long threads and dense mats under the ice (Gutt 1995). Overall, A. baicalensis is a low-temperature species adapted to the prevailing light intensities under the ice of L. Baikal. Populations can show a net increase if snow thickness is generally $<10 \mathrm{~cm}$, because sufficient solar radiation penetrates to drive both photosynthesis and convection. 
Acknowledgments We thank the members of the Limnology Institute of the Russian Academy of Sciences, M. A. Grachev, Ye. Likhoshway, N. Bondarenko, N. Guselnikova, L. A. Gorbunova, M. N. Shimaraev, V. Tsekhanovsky, L. Olbolkina, V. A. Olbolkin, O. Molozhavaya, A. Kuzmina, N. Melnik, L. Granina and L. Doroschenko. We are also grateful for the help of C. E. Gibson, I. Heaney, M. Sturm, A. Mackay, R. Flower and R. W. Battarbee. We also thank the Royal Society and Russian Academy of Sciences Siberian Division, who have supported parts of this work. We thank K. Salonen and reviewers for helpful comments on the manuscript.

\section{References}

Bidoshvili YeD, Bondarenko NA, Sakirko MV, Khanayev IV, Likhoshway YeV (2007) The change in the length of colonies of the planktonic diatom Aulacoseira baicalensis in various stages of the annual cycle in Lake Baikal. Hydrobiol J 43:79-86

Bondarenko NA, Timoshkin OA, Ropstorf P, Melnik NG (2006) The under-ice and bottom periods in the life cycle of Aulacoseira baicalensis (K. Meter) Simonsen, a principal Lake Baikal alga. Hydrobiol J 568:107-109

Cronberg G, Gelin C, Larsson K (1975) Lake Trummmen restoration project. II. Bacteria, phytoplankton and phytoplankton productivity. Verh Int Ver Limnol 19:10881096

Fietz S, Kobanova G, Izmest'eva L, Nicklisch A (2005) Regional, vertical and seasonal distribution of phytoplankton and photosynthetic pigments in Lake Baikal. J Plankton Res 27:793-810

Grachev MA, Vorobyova SS, Likhoshway YV, Goldberg EL, Ziborova GA, Levina OL, Khlystov OL (1998) A highresolution diatom record of the palaeoclimates of East Siberia for the last 2.5 My from Lake Baikal. Quart Sc Rev 17:1101-1106

Granin NG, Jewson D, RYu Gnatovsky, Levin LA, Zhdanov AA, Averin AI, Gorbunova LA, Tsekhanovskii VV, Doroschenko LF, NYu Mogilev (1999) Turbulent mixing in the water layer just below the ice and its role in development of diatomic algae in Lake Baikal. Dokl Akad Nauk 366:835-839

Granin NG, Jewson D, RYu Gnatovsky, Levin LA, Zhdanov AA, Averin AI, Gorbunova LA, Tsekhanovskii VV, Doroschenko LF, Minko NP, Grachev MA (2000) Turbulent mixing under ice and the growth of diatoms in Lake Baikal. Verh Int Ver Limnol 27:2812-2814

Gutt J (1995) The occurrence of sub-ice algal aggregations off northeast Greenland. Polar Biol 15:247-252

Jewson D (1975) The relation of incident radiation to diurnal rates of photosynthesis in Lough Neagh. Int Rev ges Hydrobiol 60:759-767

Jewson DH, Wood RB (1975) Some effects on integral photosynthesis of artificial circulation of phytoplankton through light gradients. Verh Int Ver Limnol 19:10371044
Jewson DH, Granin NG, Zhdarnov AA, Gorbunova LA, Bondarenko NA, Gnatovsky RYu (2008) Resting stages and ecology of the planktonic diatom Aulacoseira skvortzowii in Lake Baikal. Limnol Oceanogr 53:11251136

Jónasson P, Adalsteinsson H (1979) Phytoplankton production in the shallow eutrophic Lake Mývatn, Iceland. Oikos 32:113-138

Kelley DE (1997) Convection in ice covered lakes: effects of algal suspension. J Plankton Res 19:1859-1880

Kozhov M (1963) Lake Baikal and its life. Junk, The Hague

Kozhova OM (1987) Phytoplankton of Lake Baikal: structural and functional characteristics. Arch Hydrobiol Beih Ergebn Limnol 25:19-37

Kozhova OM, Izmest'eva LR (1998) Lake Baikal, Evolution and Biodiversity. Backhuys, Leiden, pp 1-23

Likoshway YV (1999) Fossil endemic centric diatoms from Lake Baikal, Upper Pliestocene complexes. In: Mayama S, Idei M, Koizumi I (eds) 14th Diatom Symposium 1996. Koeltz, Koenigstein, pp 613-628

Lund JWG (1966) Znachenie turbulentnosti vody v priodichnosti razvitiya nekotorykh presnovodnyh vidov roda Melosira (Algae). Bot Zh Kyyiv 51:176-187

Mackay AW, Ryves DB, Battarbee RW, Flower RJ, Jewson DH, Rioual PMJ, Sturm M (2005) 1000 years of climate variability in Central Asia: assessing the evidence using Lake Baikal diatom assemblages and the application of a diatom-inferred model of snow thickness. Glob Planet Change 46:281-297

Nauwerck A (1963) Die Beziehungen zwischen zooplankton und phytoplankton in See Erken. Symb Bot Ups 17:1-163

Popovskaya GI (2000) Ecological monitoring of phytoplankton in Lake Baikal. Aquat Ecosyst Health Manag 3:215-225

Richardson TL, Gibson CE, Heaney SI (2000) Temperature, growth and seasonal succession of phytoplankton in Lake Baikal, Siberia. Freshw Biol 44:431-440

Rodhe W (1955) Can plankton production proceed during winter darkness in sub-arctic lakes? Verh Int Ver Limnol 12:117-122

Sherstyankin PP (1975) Experimental studies of the underwater light field in Lake Baikal. Nauka, Moscow, pp 1-91 in Russian

Shimaraev MN, Verbolov VI, Granin NG, Sherstyankin PP (1994) Physical Limnology of Lake Baikal: a Review. Print No. 2. Baikal International Center for Ecological Research, Irkutsk

Skabichevsky AP (1929) On the biology of Melosira baicalensis (K. Meyer). Russ Hydrobiol J 8:93-114 in Russian

Straškrabová V, Izmest'yeva LR, Maksimova EA, Fietz S, Nedoma J, Boroveca J, Kobanova GI, Shchetinina EV, Pisleginac EV (2005) Primary production and microbial activity in the euphotic zone of Lake Baikal (Southern Basin) during late winter. Glob Planet Change 46:57-73

Zhdanov AA, Granin NG, Shimaraev MN (2001) The generation mechanisms of under-ice currents in Lake Baikal. Dokl Earth Sci A 377:329-332 